\title{
EU Climate and Energy Policy: New Challenges for Old Energy Suppliers
}

\author{
Indra Overland
}

\section{The Future EU Energy Demand Mix}

Much recent research on the EU's international energy policy analyses how the EU seeks to enforce its energy rules outside the union, for example, in the antitrust case against Gazprom or in the regulatory battles over the Nord Stream pipelines (see Andersen, Goldthau, \& Sitter, 2017; also Chaps. 2 and 3 in this volume). Another strand of the literature focuses on the geopolitics of energy, energy security and energy-related tensions with Russia (see Cwiek-Karpowicz, Godzimirski, \& Nowak, 2015; Romanova,

This chapter is a product of the EUNOR project, financed by the Research Council of Norway's programme 'Europe in Transition (EUROPA)', and the RusCasp project, financed by the Research Council of Norway's programme PETROSAM. I am grateful to Ole Gunnar Austvik, Elin Lerum Boasson, Jakub M. Godzimirski, Andreas Goldthau, Kristin Haugevik, Bård Lahn, Nick Sitter, Svend Søyland and Karen Sund for their suggestions. Needless to say, I remain responsible for the contents of the chapter-they may not even agree with some of my points. All translations from Norwegian are my own.

I. Overland $(\bowtie)$

NUPI - Norwegian Institute of International Affairs, Oslo, Norway

e-mail: ino@nupi.no

(C) The Author(s) 2019

J. M. Godzimirski (ed.), New Political Economy of

Energy in Europe, International Political Economy Series, https://doi.org/10.1007/978-3-319-93360-3_4 
2016; Sharples, 2016; Orttung \& Overland, 2011). While such topics have received considerable attention, EU climate policy is likely to have far greater consequences for international energy relations than geopolitics or regulatory expansion.

The EU has pledged to reduce its greenhouse gas emissions by 40 per cent from 1990 levels by 2030 (EC, 2015). The work towards this objective has two main pillars: energy efficiency and renewable energy. By 2030, half of the EU's electricity supply is to be generated from renewables, and by 2050 it is to be fully decarbonized (EC, 2016). ${ }^{1}$ These policy areas are currently (in 2018) undergoing revision and further details are being hammered out. Future EU energy policy is likely to be even more ambitious.

The EU imports more oil and gas than any country in the world (EIA, 2016). If fulfilled, the EU's combined energy efficiency and renewable energy objectives will render fossil fuels a shrinking slice of a shrinking energy demand pie.

In this chapter, I first provide a brief overview of the implications of changes in EU energy demand for the major external energy suppliers. I then examine the Norwegian case in some detail, assessing whether and how Norway has made efforts to prepare for the energy transition. For reasons discussed below, Norway is particularly well positioned for adapting to such a transition and therefore represents a best case for the EU's external energy suppliers. Whatever Norway is unable to do, the others will be even less likely to achieve.

\section{Prospects for the External Energy Suppliers}

The countries that export most fossil fuels to the EU are Algeria, Colombia, Kazakhstan, Nigeria, Norway, Russia, Saudi Arabia and the USA (see Fig. 4.1). For these countries, any changes in the EU energy demand mix should be of concern.

The EU's external suppliers are rule-takers, not rule-makers: no matter how the EU energy mix evolves, they will have to adapt. ${ }^{2}$ Despite being closely integrated with the EU, even Norway has little say over EU energy policy formulation (see Chap. 6 in this volume). This is even more true of the other external energy suppliers, including great-power Russia,

\footnotetext{
${ }^{1}$ For a broader overview of the evolution and many mechanisms of EU climate and energy policy, see Boasson and Wettestad (2013).

${ }^{2}$ For more on their adaptation, see Chap. 3 of this volume; on how they may try to influence EU energy policy choices, see also Chap. 5.
} 


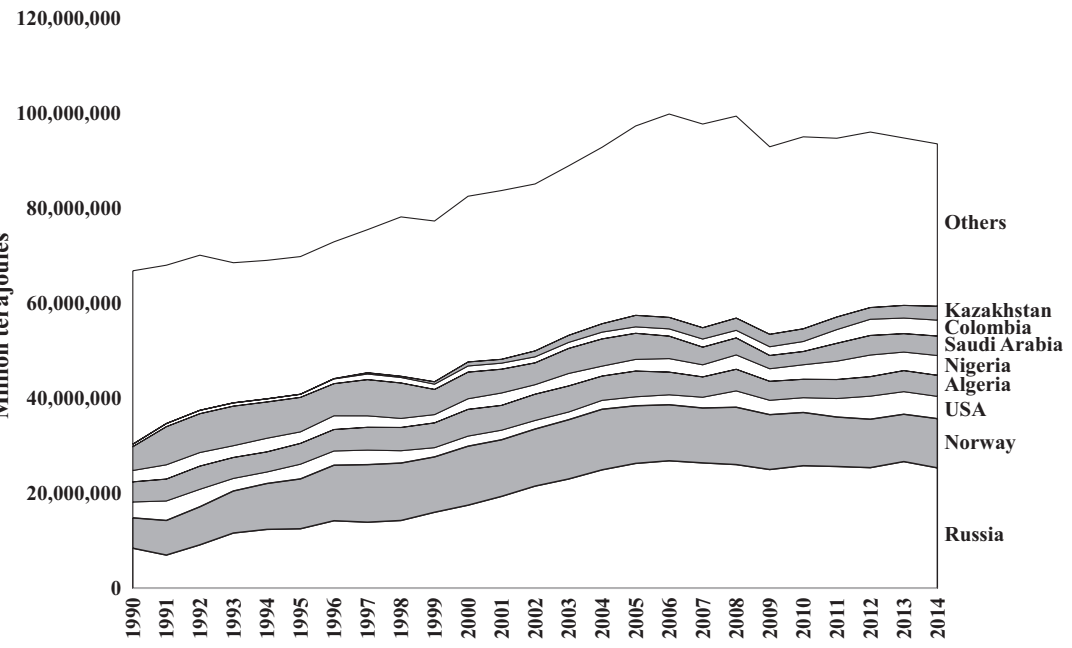

Fig. 4.1 EU28 coal, oil and gas imports by origin, recalculated as terajoules, by country of origin (data source: Eurostat, 2017a)

which is being forced by EU regulators to change its ways when it comes to free-market competition (Overland, 2017, p. 125).

How decarbonization will affect demand for different types of fossil fuel is hard to predict. Logically, it is the EU's coal imports that should be cut the most and the fastest: coal produces most GHG emissions and is a major cause of air pollution and acid rain at the local and regional levels, and imported coal competes with coal produced within the EU. For external suppliers of coal to the EU such as Australia, Colombia, South Africa and the USA, the outlook for this part of their exports is bleak, although they may attempt to redirect them to other markets, as coal is a flexible commodity. However, if other markets follow the EU in trying to phase out coal, this flexibility will not help.

For the EU's oil suppliers, the situation is less clear but also bleak. The potential for increased use of bicycles, electric bicycles, public transport and electric passenger vehicles is greater in the EU than in most other parts of the world, because Europe's cities were largely designed before the motorization of transport, featuring narrow streets and compact urban centres. However, to an even greater extent than coal, oil is a fungible, global commodity, and developments in the EU are therefore not necessarily decisive for oil producers. On the other hand, if disruptive technologies 
are developed for energy storage in the transport sector, oil consumption may be drastically reduced throughout the world.

The situation for natural gas is even more ambivalent. Around 2011, there was considerable enthusiasm for natural gas as a bridge fuel to a lowcarbon energy system, but some of this excitement has since abated (Zhang, Myhrvold, Hausfather, \& Caldeira, 2016a). The future of natural gas is now less bright or at least less clear than it was then. However, gas has a special position in the EU context because most gas exported to the EU is shipped via a network of pipelines that lock the EU to its suppliers. On the other hand, LNG is developing rapidly and may alleviate some of the problems of current and future gas suppliers looking for new markets for their gas, depending on how the policy framework for $\mathrm{CO}_{2}$ emissions from LNG liquefaction evolves (Ulvestad \& Overland, 2012).

According to Sweijs et al. (2014, p. 67), Algeria and Russia are particularly exposed to the European energy transition, because large shares of their export earnings come from oil and gas, and most of it is sold to EU customers (Table 4.1). China and Russia have agreed to expand their natural gas trade to 38 billion cubic metres $(\mathrm{bcm})$ per year upon completion of the Power of Siberia pipeline (scheduled for December 2019), but this pales compared with the approximately $160 \mathrm{bcm}$ that Russia exports to Europe (Overland, 2018a). Along with Libya and Norway, Algeria and Russia are also welded to Europe by natural gas pipelines-though both also have the capacity to export LNG.

Table 4.1 Major exporters to the EU

\begin{tabular}{lcccc}
\hline & $\begin{array}{c}\text { Oil and gas income as } \\
\text { \% of state budget }\end{array}$ & $\begin{array}{c}\text { \% of oil exports } \\
\text { going to the EU }\end{array}$ & $\begin{array}{c}\text { \% of gas exports } \\
\text { going to the EU }\end{array}$ & $\begin{array}{c}\text { \% of coal exports } \\
\text { going to EU }\end{array}$ \\
\hline Algeria & 60 & 72 & 90 & 46 \\
Colombia & 20 & 9 & 100 & 47 \\
Libya & 96 & 71 & 58 & \\
Nigeria & 70 & 40 & 97 & 34 \\
Norway & 14 & 97 & 30 & 42.6 \\
Qatar & 60 & 79 & 81 & \\
Russia & 52 & 15 & 7 & \\
S. Arabia & 90 & 6 & & \\
USA & 0.2 & & & \\
\hline
\end{tabular}

Sources: Sweijs et al. (2014, p. 67), Trademap (2017) 
As noted, oil suppliers may be somewhat less vulnerable to changes in EU demand, so Saudi Arabia may be better positioned in this regard. However, the Saudis will be equally vulnerable if new technologies are developed and/or other parts of the world fulfil the Paris Agreement (O'Sullivan et al., 2017; Overland, 2015).

For Colombia, Kazakhstan, Nigeria, Saudi Arabia and the USA, distance rules out transitioning from the export of fossil fuels to the export of renewable energy to the EU. Although Russia shares direct borders with the EU, Russia's options are also limited, as most of its landmass is located far away from the main demographic and economic centres of the EU and because there are internal Russian policy constraints on the development of renewable energy except for large-scale hydropower (Overland \& Kjaernet, 2009).

Algeria, Morocco and Tunisia have good preconditions for building large-scale solar arrays for export of electricity to the EU, but none of these countries is closely aligned with Europe. Moreover, in Algeria and Tunisia, there could be stability concerns, as illustrated by the 2013 attack on the Tigantourine gas facility in Algeria. Finally, the Desertec project for creating renewable energy 'super grids' by harnessing power from renewable energy sites in North Africa for consumption in Europe has already been shelved. That is not a positive sign-though such a project might resurface in some form due to the excellent climatic and geographical conditions.

The Norwegian case is of particular interest because some 97 per cent of Norwegian oil and gas exports go to the EU-moreover, Norway is by far the best positioned of the major external suppliers to adapt to the ongoing changes in EU energy demand. Therefore the remainder of this chapter focuses on how Norway has been handling changes in the EU energy demand mix.

\section{Another Stroke of Luck for the EU's Small, Large Energy Supplier?}

Norway stands out in several ways. First, although also Norway is welded to Europe by pipelines, unlike the other external energy suppliers, Norway is a West European country with an ambitious climate discourse and policy increasingly integrated with those of the EU (Boasson \& Lahn, 2017, p. 195). That should make it better attuned to policy developments in the EU. 
Second, while only Russia supplies more fossil fuels to the EU, Norway is a much smaller country, without a history as a great power, Cold War protagonist or involvement in energy conflicts with transit countries. This reduces the amount of perceived risk associated with Norwegian energy supplies.

Third, after the turn of the millennium, the share of natural gas in Norway's hydrocarbon production mix has grown. This is a positive development, given the lower carbon footprint of natural gas; moreover, Norway already has in place both pipelines and a liquefied natural gas (LNG) facility for natural gas exports.

Fourth, Norway's greatest comparative advantage over its energy supplier peers lies not in the petroleum sector but in renewable energy. Norway is Europe's biggest producer of hydropower, due to its maritime climate with significant precipitation and its geology of glacial, bare bedrock valleys, which make dam construction easier and safer than in younger mountainous regions of the world. ${ }^{3}$

Fifth, the large reservoir capacity of the Norwegian hydropower dams, amounting to around half of total European capacity, means that Norway can fulfil a balancing function, turning up electricity production when neighbouring countries produce less and reducing it when they produce more (Lindström \& Ruud, 2017; Solvang et al., 2014). Thus, Norway can in theory help balance against the intermittency of both wind and solar power in the EU and the production of wind power in Norway for export to the EU. This is sometimes referred to as functioning as a 'green battery' (Gullberg, 2013, p. 615).

Sixth, Norway has some of the greatest wind resources in Europe. Norway's 100,000 km coastline is one of the world's longest, and it includes 320,000 islands and reefs as well as many capes and peninsulas (Staurset, 2011). This special geography creates a remarkable potential for wind power, as it makes it possible to capture powerful maritime winds with wind turbines bolted to the bedrock onshore-which is simpler and cheaper than constructing offshore wind turbines.

Seventh, Norway's location is an advantage, with proximity to the wealthiest EU member states, which happen to have the greatest need for heating and some of the most ambitious climate policies: Denmark, Finland, Germany, Sweden and the UK. The Nord Pool market for trading

\footnotetext{
${ }^{3}$ Russia produces more hydropower than Norway, but several of its major dams are outside Europe, in Siberia and the Far East.
} 
electricity across Northern Europe also makes it relatively easy to exchange electricity between Norway and its neighbours (de Menezes \& Houllier, 2015; Mirza \& Bergland, 2015).

Eighth, the expertise of Norway's petroleum service industry may be used for developing renewable energy. This pertains especially to floating offshore wind power, where Norway's national oil company, Equinor (formerly Statoil), aims for a leading position (Sxtre, 2017a).

With its many advantages, Norway represents a best-case scenario among the EU's external energy suppliers. Or, put differently: if Norway cannot anticipate and position itself for a decarbonized energy demand scenario, the other fossil fuel suppliers are likely to be even less prepared.

\section{How Has Norway Positioned Itself for the EU's ENERgy Transition?}

Norway's track record on climate and energy policy includes some significant achievements. For example, a $\mathrm{CO}_{2}$ tax on petrol and other oil products was introduced as early as 1991 and made up around half of the retail price of petrol in 2018 (Njarga, 2016; Bruvoll \& Larsen, 2004). This is particularly impressive when compared to many other countries with large oil reserves, like Iran, Nigeria, Saudi Arabia and Venezuela, where merely removing subsidies for petrol has proven difficult, let alone introducing carbon taxes (Dansie, Lanteigne, \& Overland, 2010; Overland, 2010).

The $\mathrm{CO}_{2}$ tax is not Norway's only contribution to climate mitigation. Norway has ambitioned to be a front runner in international climate policy since the 1980s (Lahn \& Wilson Rowe, 2015); it has pioneered the concept of international carbon trading (Sæverud \& Wettestad, 2005; Boasson \& Lahn, 2017), helped to initiate the REDD programme to preserve tropical forests as carbon sinks (Edwards, Fisher, \& Boyd, 2010; Hermansen, 2015; Matthews et al., 2014), pioneered the replacement of bunker oil with LNG in shipping through the creation of the NOx Fund (Pinchasik \& Hovi, 2017), and introduced serious support for electric vehicles earlier than most countries (Bjerkan, Nørbech, \& Nordtømme, 2016; Mersky, Sprei, Samaras, \& Qian, 2016; Ryghaug \& Toftaker, 2016; Zhang, Qian, Sprei, \& Li, 2016b). Thus Norway's climate policy stands out compared to those of other oil-producing countries, including wealthy and democratic oil-producing peers Australia and Canada (Friedrichs \& Inderwildi, 2013; Boasson, 2013). 
However, none of these initiatives relate specifically to Norway's energy relations with the EU-the destination of almost all Norwegian energy exports. In the rest of this section, I therefore assess Norway's contribution to the EU's energy transition in several areas of policy and business, focusing on the strategic choices and actions of the Norwegian government and the country's largest company, Equinor.

\section{Natural Gas Vehicles}

Natural gas vehicles have lower greenhouse gas emissions and produce less local air pollution than petrol and diesel vehicles (Hesterberg, Bunn, \& Lapin, 2009). Regular petrol cars can be modified to run on natural gas, and the cost is easily recouped due to the lower cost of natural gas. Almost all countries in Europe have extensive gas grids, ensuring that natural gas is easily available. If there is one area where natural gas might play a major role as a transition fuel between the oil era and a decarbonized energy system, it is in European road transport.

Paradoxically, however, most European countries except for major gas importers Italy and Poland have been slow to adopt natural gas vehicles compared to countries less well positioned for this, for example, Armenia, China, India and Pakistan. One important reason may be that Europe's main external suppliers of natural gas-Norway and Russia-were long passive about promoting its use for road transport, failing to seize an opportunity that both countries could have benefitted from. ${ }^{4}$ As sales of electric battery (and in the future possibly fuel cell) cars surge, the window of opportunity for natural gas vehicles may already be closing.

\section{Sale of Filling Stations}

A decisive moment in the failure to promote natural gas for the European transport sector came in 2012, when Equinor sold off its chain of filling stations. The chain included around 2290 stations serving over one million customers daily across Northern and Eastern Europe and is now part of the brand Circle K (Nordea, 2016, p. 2).

\footnotetext{
${ }^{4}$ Gazprom launched the Blue Corridor rally for NGVs in 2008 and collaborates with major European carmakers in promoting NGVs (Bieliszczuk, 2017: 2). Although more impressive than the Norwegian non-effort, these initiatives have had limited impact.
} 
The filing stations could have been used as a platform for promoting natural gas vehicles and later for moving into emerging business areas such as hydrogen tanking, charging electric vehicles or rapid exchanging (rather than recharging) of batteries. When the Equinor filling stations were sold, the rationale was that petrol retail was such a competitive sector and the profits so marginal that it had become difficult to make money on anything other than sales of hotdogs and coffee. During this period, Equinor also seemed to be operating on the unstated assumption that climate policy would not have significant impact on the demand for oil and gas. The company argued that the world still needed more energy to eradicate energy poverty and claimed that Norwegian oil and gas were cleaner than those of other countries and therefore represented a lesser evil (Bjørnestad \& Barstad, 2017). During the same period, Equinor was investing heavily in Canadian oil sands, having ramped up this business area around 2010. Had Equinor taken climate policy more seriously sooner, it might instead have kept its filling stations and used them to navigate the energy transition.

\section{Mixing Hydrogen into Natural Gas}

The combination of natural gas production and renewable energy resources creates interesting opportunities for Norway. Hydrogen could be produced from renewable energy sources and mixed with natural gas before export, raising the calorific value of the natural gas and bundling it with renewable energy (Holst et al., 2016, p. 14). Adding hydrogen to natural gas might extend the lifespan and commercial value of Norway's $8800-\mathrm{km}$ network of export gas pipelines, raising the return on the considerable sunk costs of those pipelines.

Significant technological and marketing challenges would have to be solved before such a solution could be commercially viable. If the necessary technologies were developed successfully, they could also be sold to other natural gas producers. Some work has been done on this (Lie, $2013 \mathrm{~b}$ ), but effort in this area is miniscule compared to Norwegian investments in petroleum exploration, carbon capture and storage, LNG, American shale drilling, Canadian oil sands or subsea technology (Boasson \& Wettestad, 2014). 


\section{Wind Power Versus New Acreage for Petroleum Exploration}

According to its promotional material, Equinor aims to be a climatefriendly company (Statoil, 2017). However, Irene Rummelhoff, Director of New Energy Solutions in Equinor, has written:

Let there be no doubt: Our [oil and gas] activity in the North Sea is Statoil's [Equinor's] backbone. Here we have a proud history-and an exciting future. We are also growing internationally in oil and gas. We will thus remain an energy company focused on oil and gas for a long time (Rummelhoff, 2016).

It is not surprising that a representative of an oil company should make such a statement, but it is striking that someone so central to the company's renewable energy investments should take pains to make such a point in an op-ed in a major newspaper. It may help explain why only 3.6 per cent of Equinor's investments between 2012 and 2016 were in renewable energy (Lewis, 2017).

In 2016, Equinor announced that it would create a fund to invest a total of NOK 1.7 billion (EUR 180 million) in renewable energy over a period of four to seven years. Then in October 2017, Equinor launched Hywind, the world's first floating wind farm, off the coast of Scotland. At the same time, Equinor's CEO Eldar Srtre published an op-ed, announcing the 'ambition to invest [a total] of around NOK 100 billion' (EUR 10.5 billion) in renewable energy over the next 13 years (Sætre, 2017a). This figure may look impressive, but was dwarfed by the company's investments in its numerous oil and gas projects around the world. For example, the Johan Castberg oilfield alone was slated for investment of around NOK 60 billion over a six-year period - and that was after a 40 per cent budget slash due to the drop in the oil price (Krogh, 2016). It is also worth noting that the NOK 100 billion plan for renewable energy was not launched before 2017 and even then remained at the level of vaguely formulated intentions.

Equinor has also made significant efforts at lobbying the Norwegian authorities to open up the seas around the Lofoten and Vesterålen archipelagos to petroleum development and to reduce the taxes on its oil and gas activities in the Barents Sea (e.g. Haugan, 2016; Lysvold, 2016). By comparison, Equinor has put little effort into lobbying for better regulatory conditions for wind power investment in Norway. This is despite the fact that petroleum activity in the Arctic is controversial and could have negative impacts on the company's reputation (Saltvedt, cited in Aadland, 2015; Overland \& Krivorotov, 2015, p. 102). 


\section{Developing Wind Power to Boost Norwegian Electricity Exports}

Taking into account Norway's wind resources, as well as the rapid growth of wind power in neighbouring Denmark, Germany, the Netherlands and the UK, Norwegian wind power is underdeveloped. The Danish and Norwegian cases make for particularly interesting comparison. The two countries were one state for over 400 years and have mutually intelligible languages, the same Lutheran heritage, the same size of population, the same level of economic development and similarly ambitious climate discourses. Denmark is a small, flat, windy country where it is easy to set up wind turbines; Norway has lower population density and a windy and much longer coast with many excellent locations for wind turbines. In sum, the two Scandinavian neighbours have different but comparable starting points for the development of wind energy (Granlund, 2014, p. 6). However, while Denmark has assumed a leading role in the global wind power sector with a generation capacity of $5228 \mathrm{MW}$, Norway is a laggard with only 873 MW (Weir, 2017, p. 4; GWEC, 2017, p. 11). A glance at some of the major potential players in Norwegian wind power confirms the impression that Norway lags behind other countries.

Equinor has an excellent starting point for developing Norwegian wind power: decades of offshore and onshore experience, a dominant position on the Norwegian continental shelf, a firm grasp of the Norwegian supply industry, close connections with the Norwegian state and high status in Norwegian society. Nonetheless, Equinor has chosen to invest in wind power in the UK and the USA rather than Norway.

Also the Danish wind power giant Vestas had a good starting point for expanding into Norway, considering the geographical and cultural proximity of the two countries. Vestas had a head start in Norway, erecting its first Norwegian wind turbine as early as 1989 and first wind farm in 1991. Nonetheless, Norway has not become an important part of Vestas' business.

The Swedish energy company Vattenfall owns over 1000 wind turbines producing a total of almost 6 TWh per year of electricity in 2016 in Sweden, Denmark, Germany, the Netherlands and the UK (Vattenfall, 2017). Thus, Vattenfall has been investing heavily in wind power in most countries in the region-except Norway.

General Electric bought Norwegian wind turbine manufacturer ScanWind and planned to open a research centre for offshore wind power in Oslo but gave up after one year. And in 2017 Statkraft, Norway's state-owned power 
company, was in the process of withdrawing from offshore wind power, selling its shares in several wind farms (Riisnæs, 2017).

By 2017, there were plans for several new major wind farms in Norway-but still, Norway has been slow to seize the opportunities offered by its climate and geography. While resting on its century-old hydropower laurels, Norway has failed to fulfil its potential as a supplier of wind power to the EU. Reasons for the slow development of wind power in Norway include lack of a favourable regulatory framework, long waiting times for concessions and lack of incentives (Rygg, 2015). Above all, the low price of electricity in Norway has served to limit the development of wind power, a topic I return to later on in the chapter.

\section{Electricity Interconnectors}

Norway alone has around half of Europe's hydropower storage capacity, a good starting point for functioning as the continent's green battery (Killingtveit, 2016, p. 4). A major precondition for fulfilling this potential is the existence of sufficient infrastructure for the exchange of electricity between Norway and the EU countries. Norway already has electricity interconnectors with Denmark, the Netherlands and Sweden. Along with the Nord Pool electricity exchange and the Norwegian-Swedish green certificate system for renewable energy, the existing interconnectors ensure that the Norwegian electricity system is partially integrated with those of its neighbours and already functions as a power bank for Danish wind power. However, the ongoing expansion of renewable energy production in many EU countries opens up the possibility for Norway to function as a green battery on a significantly greater scale.

Germany's experience in December 2016 illustrates the need for this. A protracted period of dense fog and lack of wind, combined with lack of interconnectors and coordination between electricity market actors in different parts of the country, led to problems with the German electricity supply, exposing some challenges involved in the rapid expansion of solar and wind power (Flassbeck, 2016). Norwegian energy storage can help to safeguard against such events-provided there is sufficient high-voltage transfer capacity between EU countries and Norway.

Using Norway as a green battery is a win-win arrangement for Norway and the EU. It can increase Norway's export earnings, mitigate the energy security concerns of EU countries related to the intermittency of solar and 
wind power and make it possible to store rather than waste their surplus of clean energy production. Thus, it can increase the viability of the EU's own renewable energy production and facilitate increased imports of renewable energy while also bringing significant financial benefits to Norway. As both sides have strong incentives, this may be some of the lowest-hanging fruits in international climate and energy cooperation. EU actors have called for the development of energy storage capacity, indicating that Norway could provide part of the solution (EC, 2011, p. 34; German Advisory Council on the Environment, 2011; Moser, Maaz, Baumann, \& Schäfer, 2015). As Gullberg (2013, p. 615) notes, using Norway as a green battery for Europe is certainly technically feasible: the question is whether it is politically and economically feasible. One might add: for the Norwegian side.

Many of the experts who have analysed or commented on Norway's potential as a green battery have been enthusiastic (Gullberg, 2013, p. 615; Hagem, 2016). However, much of the public debate on the required expansion of electricity interconnectors has been negative, as they are expected to lead to higher electricity prices within Norway. The Norwegian Union of Industry and Energy Workers has been staunchly opposed (Gullberg, 2013, p. 619). Hogne Hongset, former Director of Communications in Equinor, warned in Verdens Gang, Norway's most widely circulated newspaper, that Norwegian electricity consumers are being conned and that the companies that want to build cables to other countries are more interested in raising electricity prices for their Norwegian customers than in expanding exports. He also stated that the companies 'use climate arguments that have no substance at all', without providing further explanation (Hongset, cited in Haugan \& Vågenes, 2016). Other examples of the critical, often angry, discourse against the expansion of electricity interconnectors with other countries include Gjelsvik (2017), Sxtre (2017b), Handegård (2016, 2017), Braanen (2017), Byrkjeflot (2017) and Klassekampen (2015). An editorial in the newspaper Rogalands Avis (2013) is particularly vitriolic:

The sum of all this is that the [Norwegian] consumers in the coming years will be burdened with colossally overpriced electricity bills, while the Norwegian electricity system will become as costly and chaotic as those of most EU countries. This boundless insolence will be the greatest scam in Norwegian history if the electricity industry has its way for another ten years and its greed is not reined in. 
In addition to disregarding Norway's contribution to ensuring the success of the EU's energy transition, this discourse ignores the point that raising Norway's low electricity prices is actually a good thing in its own right, creating incentives to improve energy efficiency. Higher electricity prices for Norwegian consumers could be seen not as a negative side-effect of expanded interconnected capacity but as an objective.

\section{Electricity Pricing}

Limiting the number of interconnectors would not only restrict Norway's prospects as a green battery but also help keep Norwegian electricity prices low, thereby limiting the incentives to develop areas such as wind power, small hydro and pumped-storage hydropower. The consequences of low electricity prices are illustrated by the modernization of hydropower. The most cost-efficient way of increasing renewable energy production in Norway is to modernize the country's existing hydropower plants. Many of them were built between the 1930s and 1960s; some have since been modernized, while others could still attain greater efficiency. However, with the limited capacity for power exports and the consequent low electricity prices in Norway, there have been few incentives for modernization.

In practice, resistance to the installation of electricity interconnectors is a call for the equivalent of large-scale indirect subsidies for Norwegian electricity consumption. Producers are forced to sell electricity at lower prices in the domestic market than they could have obtained in foreign markets, thus keeping domestic prices lower in Norway than in almost any other European country (see Fig. 4.2). This is comparable to countries such as Iran, Saudi Arabia and Venezuela, which have subsidized petrol consumption by limiting exports to the world market, where the oil would have fetched a higher price (Cheon, Lackner, \& Urpelainen, 2014; Mundaca, 2017). Although hydropower does not generate significant greenhouse gas emissions, the general principle of de facto indirect subsidization is similar. The categorization of such indirect price-limiting mechanisms as subsidies is also supported by the use of the price-gap method as one of the standard approaches to identifying energy subsidies (Koplow, 2009, pp. 1-2; Kojima \& Koplow, 2015, p. 6; Overland, Suryadi, \& Win, 2016, p. 9; Overland \& Kutschera, 2011). ${ }^{5}$

\footnotetext{
${ }^{5}$ In the price-gap method, the size of a subsidy is estimated by calculating the difference between the price that end users in a given country have to pay and the market price, often the price on world markets adjusted for transport and distribution costs.
} 

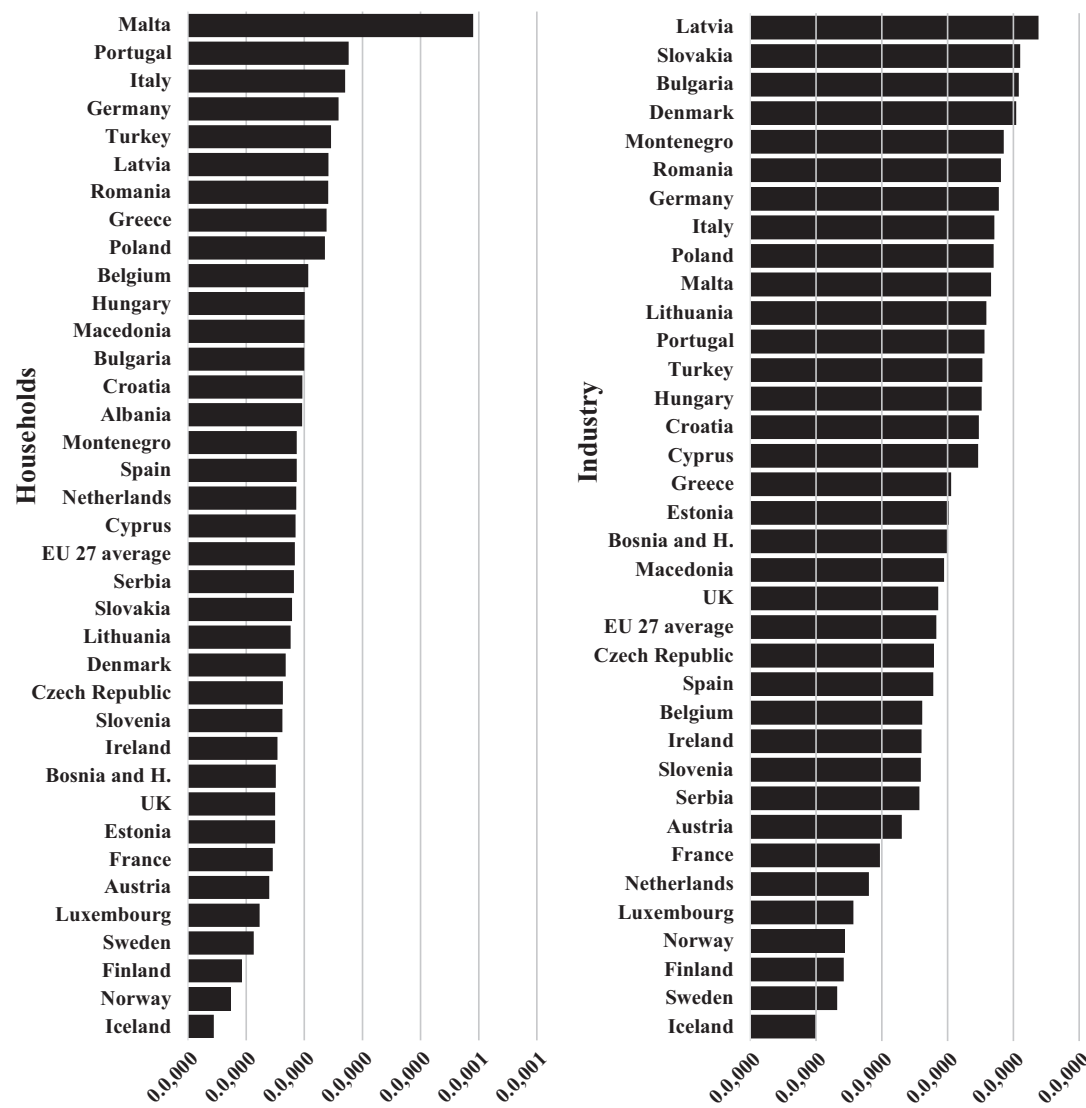

Fig. 4.2 Cost of electricity in European countries, in purchasing power standardized currency units, adjusted for taxes (data source: Eurostat, 2017b)

\section{Is the Glass Half-Full or Half-Empty?}

I set out to appraise Norway's effort to prepare for and contribute to the EU's energy transition. However, what yardstick this effort should be measured by is not clear. The difficulty can be illustrated with a public debate that took place in 2017 between Kjell Roland and Torger Lien on the one hand and Per Sanderud on the other.

According to Roland and Lien (2017, p. 28), Norway has failed to promote products and pricing structures that facilitate payment for its 
capacity to function as a green battery. As a result, $1 \mathrm{kWh}$ of flexible Norwegian hydropower does not earn a premium over $1 \mathrm{kWh}$ of inflexible Danish wind power. According to Roland and Lien (2017, p. 28), the lack of a more proactive Norwegian approach towards Brussels and the EU countries is an 'incomprehensible' paradox. Sanderud, Director of the Norwegian Water Resources and Energy Directorate, disagrees with Roland and Lien, arguing that the Norwegian authorities are working hard to create the conditions for Norway to become a green battery for Europe (Sanderud, 2017).

The decisive question in the discussion between Roland, Lien and Sanderud-and for this chapter-is whether Norway has done enough and, by extension, how much is enough. This question concerns not only the green battery issue and the installation of electricity interconnectors but also all the areas discussed above, including the promotion of natural gas vehicles, mixing of hydrogen into natural gas and facilitating the development of Norwegian wind power. Although it is difficult to find objective criteria by which to resolve such discussions, there are some strong arguments in favour of concluding that Norway has not fulfilled its potential for positioning itself for, or contributing to, the EU's energy transition.

First, as one of the countries in the world that has profited most from international oil and gas consumption, Norway has a particular responsibility for mitigating climate change (Fuglestvedt \& Kallbekken, 2015; Rive, Torvanger, \& Fuglestvedt, 2006). Viewed from the perspective of climate justice, Norway's contribution to mitigating climate change should not be half-hearted.

Second, in climate mitigation, time is of the essence (den Elzen et al., 2017, p. 15; Blok et al., 2017, p. 37). Rapid action is important not only because greenhouse gas emissions need to be cut fast but also because it can provide an infrastructural basis for developing renewable energy in other countries and because it sends market and policy signals to all the actors who are trying to second-guess future developments. As Sanderud and many Norwegian ministers have argued while championing government policy, Norway has managed to get many things right in its climate and energy policies. But have the measures come early enough? In each of the areas discussed above, one can ask, 'Could Norway have acted earlier than it did?' In most cases, the answer is probably 'yes'. In some cases, Norway might have acted a decade earlier. 
Third, the EU has been emitting strong climate policy signals since the early 1990s (Oberthür \& Pallemaerts, 2010). The 1990 report of the Intergovernmental Panel on Climate Change (IPCC) almost immediately triggered a debate in the European Council; that same year, European leaders agreed to stabilize greenhouse gas emissions at 1990 levels by 2000 (European Council, 1990). From then on, the EU has sought to take a proactive stance in climate and energy policy, within Europe and globally, with initiatives like the ALTENER renewable energy targets (adopted in 1993) and by playing leading role in negotiations and implementation of the Kyoto Protocol (adopted in 1997). A particularly important policy signal was the approval in 2007 of the 20-20-20 targets: by 2020 , the EU was to reduce emissions of greenhouse gases by 20 per cent, increase energy efficiency by 20 per cent and achieve 20 per cent of renewables in total energy consumption (Arababadi, Moslehi, El Asmar, Haavaldsen, \& Parrish, 2017; Calvin et al., 2014). It is also worth remembering that the EU was originally founded in 1951 as the European Coal and Steel Community, which helped avoid a repeat of the world wars by regulating competition between the European powers in the energy and industrial sectors. EU energy policy signals should therefore carry some weight.

Fourth, as noted above, the EU countries have sent positive signals specifically about Norway's potential role as a green battery. Germanyprobably the most important potential market for Norwegian renewable energy cooperation - has been especially vocal here.

Fifth, in all the issue areas discussed in this chapter, Norway has a national economic self-interest in positioning itself for the EU's energy transition. Taking a proactive stance should therefore be relatively easy for Norway-compared to the other major external energy suppliers such as Algeria, Nigeria or Russia, or compared to an EU country such as Poland, where phasing out coal is socially and economically painful.

\section{Why Has Norway Procrastinated?}

\section{A Dual Resource Curse}

One possible reason for Norway's tardiness is the perennial challenge of fighting off 'Dutch disease', as easy oil income drives up prices in Norway and draws labour and investors away from nonpetroleum activities. In addition, hydropower is abundant. Consequently, Norwegian climate and 
energy policy, and especially the wind industry, struggle against a dual resource curse: of oil and of hydropower. Although Norway has largely escaped other aspects of the resource curse such as corruption, authoritarianism and internal conflict (Overland, 2018b, p. 217), the easy, rich rents from these two sectors have distracted the country from other possibilities.

\section{Path Dependency}

A major hindrance to adapting to the energy transition can come from path dependency and societal inertia within the energy-exporting countries, sometimes referred to as 'carbon lock-in' (Unruh, 2000). Norway is anchored in the petroleum sector in several ways:

- Sunk costs related to the large number of oil platforms on the Norwegian continental shelf, $8800 \mathrm{~km}$ of subsea gas pipelines, an LNG plant at Hammerfest and a major oil refinery at Mongstad

- The status of Equinor as the country's largest and most prestigious company

- An extensive offshore oil and gas supply industry, with companies based in many parts of the country

- Educational institutions geared towards the petroleum sector

- Norwegian and foreign investors with long traditions of investing in the sector

- Around 180,000 employees in the petroleum sector

- Well-organized and vocal oil workers' unions and employers' unions

- Government dependency on tax revenues from the petroleum sector

Renewable energy cannot match this in the short run. Even in Norway, where nearly all onshore electricity is generated from hydropower, the lobbying clout of the hydropower sector pales compared to that of the petroleum industry. Hydropower is highly efficient and employs hardly any people; once constructed, dams may last for centuries. Moreover, hydropower generation does not generate tax revenues anywhere near the scale of oil and gas, as most of the electricity is sold cheaply to Norwegian households and industry.

Part of Norway's carbon lock-in may also rest within the government apparatus for the energy sector, as reflected in the title 'Ministry of 
Petroleum and Energy'. ${ }^{6}$ This choice of wording indicates an oil and gas bias in two ways. Firstly, petroleum is mentioned explicitly, whereas all other energy sources are lumped together as 'energy'. Secondly, 'petroleum' comes before 'energy'. The other government units and government-controlled companies subordinated to the ministry also indicate an emphasis on the petroleum sector, with five organizations related to oil and gas, only three working on other issues, and no organization dedicated solely to wind power. The structure of the government apparatus may reflect the past of the Norwegian energy sector rather than its future.

Another aspect of the Ministry of Petroleum and Energy is that it has often been the purview of some of the country's most pro-oil politicians. The last three Ministers of Petroleum and Energy-Ola Borten Moe, Tord Lien and Terje Søviknes - have all been staunchly pro-oil and unlikely to spearhead an energy transition. Both Lien and his predecessors have attempted to hinder the EU's adoption of ambitious energy efficiency targets, fearing that they would reduce demand for Norwegian gas (Barstad, 2014). This has reinforced the silos between climate and energy policy, which are a problem in many countries, including Norway. On the other hand, two of these ministers-Lien and Søviknes-have also been strongly in favour of the expansion of electricity interconnectors with other countries, unlike many other actors (see Lien, cited in Lie, 2013a).

\section{Energy Populism}

The resistance to the installation of electricity interconnectors can be seen as a form of energy populism. Drawing on central works in the academic literature on contemporary populism such as Mudde (2004, p. 543), Madrid (2008, p. 482) and Acemoglu, Egorov, \& Sonin, (2011), energy populism can be defined as a political discourse that pits the supposed interests of 'the people' against 'the elites', often combined with resource nationalism, suboptimal but popular economic solutions such as subsidies, and promises of an easy life. The element of energy populism in the debate on electricity interconnectors is an obstacle to Norway fulfilling its potential role as a green battery for Europe. It is paradoxical that such a phenomenon should arise in Norway, where, for example, the early introduction of the $\mathrm{CO}_{2}$ tax could be considered decidedly non-populist (see Boasson \& Lahn (2017) for further discussion of the political context).

\footnotetext{
${ }^{6}$ The Ministry of Petroleum and Energy was created as a separate entity in 1978, subsumed under the Ministry of Industry in 1992 and then reappeared as a separate ministry in 1997.
} 


\section{Blind Spots}

At least two blind spots in the Norwegian conceptualization of climate policy may also play a role. Many Norwegian actors have seen climate mitigation as a moral obligation, but they have been divided as to whether this responsibility entails a necessity to cut emissions domestically or to spend funds as cost-effectively as possible by investing them in emission cuts in lower-cost countries (Anker, 2016; Hovden \& Lindseth, 2004). The latter view has predominated in government policy, but both have featured in the public debate. Between these two main stances in the Norwegian debate, two alternative perspectives have often been lost. Firstly, climate mitigation need not be solely a moral obligation, it can also be a source of industrial opportunity and income. Secondly, although it is in many cases cheaper to spend funds on emission cuts abroad, through domestic measures Norway may be able to create precedents that influence other countries, thus achieving a greater effect.

Norway's policy on electric vehicles can serve as an illustration. One reason why electrification of transport emerged as a priority was that Norway already had a very high share of hydropower in its production of heat and electricity (onshore). Thus, electric vehicles were seen as relatively low-hanging decarbonization fruit in the specific context of the Norwegian energy mix. The public debate in Norway has focused on domestic aspects of the electrification of transport and not the importance of setting an international precedent by demonstrating the viability of such electrification or contributing to an embryonic world market for electric vehicles that could kick-start competition among car manufacturers for future growth in demand. The public debate has also largely skirted the issue of Norwegian industrial interests. When support measures for electric vehicles were introduced, Norway had its own electric vehicle manufacturing industry, which produced the small car 'Think'. Yet there was little attempt to link the measures to an industrial policy for the fledgling Norwegian car industry. And political and public interest did not take off until much later, by which time the Norwegian electric vehicle industry had gone out of business.

\section{Conclusions}

All the EU's main external energy suppliers-Algeria, Colombia, Kazakhstan, Nigeria, Norway, Russia, Saudi Arabia and the USA-will be affected by changes in the EU energy demand mix. For remote coal 
exporters to the EU such as Australia, Colombia, South Africa and the USA, the prospects for continuing this trade relationship are not good, though they may attempt to redirect some of their exports to other markets. For Nigeria, Saudi Arabia and the USA, distance makes the export of renewable energy to the EU unrealistic. Despite its closer location, Russia's options in this area are also limited. Algeria has good conditions for largescale export of solar power to the EU, but political risks are a concern.

Among the EU's external suppliers, Norway is best positioned to adapt to the changes and therefore represents a best case among the EU's external energy suppliers. Whatever Norway is unable to do, the others are even less likely to manage. Yet, despite several major climate and energy policy successes, Norway has been slow to realize its potential contribution to the energy transition in the EU. Norway's inability to seize the day appears to be caused in part by carbon lock-in, in terms of physical infrastructure and in terms of identity and institutions. At the same time, Norway is failing to use the opportunity to achieve the lock-in of renewable energy, which would not only cement the position of renewable energy in Norway but also ensure that the EU's future energy system remains bolted to Norway.

It is interesting to draw a parallel between the evolution of renewable energy and the petroleum sector in Norway. Initially, there was considerable scepticism about the prospects for developing the North Sea as a petroleum province (Overland, 2018b). In a letter to the Foreign Ministry in 1958, the Norwegian Geological Survey stated flatly: 'One can disregard the possibility that there is coal, oil or sulphur on the continental shelf along the Norwegian coast' (Geological Survey, 1958; see also Naustdalslid, 1975, p. 15). Nonetheless Phillips Petroleum was granted permission to conduct geological exploration off the Norwegian coast in 1962. In 1965, a licencing round was carried out and, in 1969, one of the world's largest oilfields, Ekofisk, was discovered. Along with later discoveries, this led to a rising wave of petroleum revenue, precipitating a fundamental shift in the country's economic and social development trajectory during the coming decades.

The birth of the Norwegian petroleum industry was driven by rising international demand for oil, growing energy security concerns related to dependency on unstable Middle Eastern oil exporters and advances in offshore petroleum technology and seismology. Now a new round of changes in international energy demand, the international politics and the emergence of new energy technologies may give rise to a new round of changes 
in Norwegian energy production and exports. The current period might prove to be the renewable energy equivalent of the dawn of the North Sea petroleum era of the late 1960s.

\section{REFERENCES}

Aadland, C. (2015). Statoil risikerer ryktet sitt på Lofoten. http://www.bt.no/ nyheter/lokalt/--Statoil-risikerer-ryktet-sitt-pa-Lofoten-288837b.html. Accessed 11 Jan 2017.

Acemoglu, D., Egorov, G., \& Sonin, K. (2011). A Political Theory of Populism (NBER Working Papers 17306). Washington, DC: National Bureau of Economic Research.

Andersen, S., Goldthau, A., \& Sitter, N. (Eds.). (2017). Energy Union: Europe's New Liberal Mercantilism? Basingstoke, UK: Palgrave Macmillan.

Anker, P. (2016). A Pioneer Country? A History of Norwegian Climate Politics. Climatic Change, March, 1-13.

Arababadi, R., Moslehi, S., El Asmar, M., Haavaldsen, T., \& Parrish, K. (2017). Energy Policy Assessment at Strategic, Tactical, and Operational Levels: Case Studies of EU 20-20-20 and U.S. Executive Order 13514. Energy Policy, 109, 530-538. https://doi.org/10.1016/j.enpol.2017.07.042.

Barstad, S. (2014). Derfor prøvde Regjeringen à stoppe EUs klimamål. https:// www.aftenposten.no/okonomi/i/GlJzx/Derfor-provde-Regjeringen-astoppe-EUs-klimamal?utm_source=Energi $+\mathrm{og}+\mathrm{Klima}+\mathrm{og}+\mathrm{Klimastiftelsens+e-}$ postliste\&utm_campaign $=5 \mathrm{dcdf} 220 \mathrm{f} 9-$ RSS_EMAIL_CAMPAIGN_ FREDAG\&utm_medium =e mail \&utm_term=0_95967 e 5 ed 6 5dcdf220f9-527087037. Accessed 3 Dec 2017.

Bieliszczuk, B. (2017). Natural Gas for the Transport Sector: Gazprom's New Market. PISM Bulletin. http://www.pism.pl/files/?id_plik=23679. Accessed 10 Dec 2017.

Bjerkan, K. Y., Nørbech, T. E., \& Nordtømme, M. E. (2016). Incentives for Promoting Battery Electric Vehicle (BEV) Adoption in Norway. Transportation Research Part D: Transport and Environment, 43, 169-180. https://doi. org/10.1016/j.trd.2015.12.002.

Bjørnestad, S., \& Barstad, S. (2017). Statoil vil utvinne mer olje for å nå klimamålet. https://www.aftenposten.no/okonomi/i/RvwJW/Statoil-vil-utvinnemer-olje-for-a-na-klimamalet. Accessed 6 Nov 2017.

Blok, K., Afanador, A., van Vuuren, D., Berg, T., Breyer, C., et al. (2017). Bridging the Gap - Sectoral Greenhouse Gas Emission Reduction Potentials in 2030. In UNEP (Ed.), The Emissions Gap Report 2017: A UN Environment Synthesis Report (pp. 27-37). Nairobi, Kenya: United Nations Environment Programme (UNEP). 
Boasson, E. L. (2013). National Climate Policy Ambitionsness: A Comparative Study of Denmark, France, Germany, Norway, Sweden and the UK (CICERO Report 2013:02). https://brage.bibsys.no/xmlui/bitstream/handle/11250/ 191980/CICERO_Report_2013-02.pdf?sequence=1 \&isAllowed=y. Accessed 7 Nov 2017.

Boasson, E. L., \& Lahn, B. (2017). Norway: A Dissonant Cognitive Leader? In R. Wurzel, J. Connelly, \& D. Liefferink (Eds.), The European Union in International Climate Change Politics: Still Taking a Lead? (pp. 189-203). London: Routledge.

Boasson, E. L., \& Wettestad, J. (2013). EU Climate Policy: Industry, Policy Interaction and External Environment. Abingdon, UK: Routledge.

Boasson, E. L., \& Wettestad, J. (2014). Policy Invention and Entrepreneurship: Bankrolling the Burying of Carbon in the EU. Global Environmental Change, $29,404-412$.

Braanen, B. (2017). Norsk kraft. http://www.klassekampen.no/article/20171020/ARTICLE/171029996. Accessed 30 Oct 2017.

Bruvoll, A., \& Larsen, B. M. (2004). Greenhouse Gas Emissions in Norway: Do Carbon Taxes Work? Energy Policy, 32(4), 493-505. https://doi.org/10.1016/ s0301-4215(03)00151-4.

Byrkjeflot, A. (2017). Professoren vil skape arbeidsplaser ved å legge ned trøndersk og norsk industri. http://www.adressa.no/meninger/ordetfritt/2017/10/10/ Professoren-vil - skape-arbeidsplasser-ved-\% C 3\% A 5 - legge-nedtr\%C3\%B8ndersk-og-norsk-industri-15431826.ece. Accessed 30 Oct 2017.

Calvin, K., Edmonds, J., Bakken, B., Wise, M., Kim, S., et al. (2014). EU 20-2020 Energy Policy as a Model for Global Climate Mitigation. Climate Policy, 14(5), 581-598. https://doi.org/10.1080/14693062.2013.879794.

Cheon, A., Lackner, M., \& Urpelainen, J. (2014). Instruments of Political Control. Comparative Political Studies, 48(3), 370-402. https://doi. org/10.1177/0010414014543440.

Cwiek-Karpowicz, J., Godzimirski, J., \& Nowak, Z. (2015). The Power of the Pipeline: Russia's Energy Policy and the EU. Osteuropa, 65(3), 151-161.

Dansie, G., Lanteigne, M., \& Overland, I. (2010). Reducing Energy Subsidies in China, India and Russia: Dilemmas for Decision Makers. Sustainability, 2(2), 475-493. https://www.researchgate.net/publication/41667826_Reducing_ Energy_Subsidies_in_China_India_and_Russia_Dilemmas_for_Decision_ Makers. Accessed 11 Nov 2017.

den Elzen, M., Höhne, N., Jiang, K., Cantzler, J., Drost, P., et al. (2017). The Emissions Gap and Its Implications. In UNEP (Ed.), The Emissions Gap Report 2017: A UN Environment Synthesis Report (pp. 11-26). Nairobi, Kenya: United Nations Environment Programme (UNEP). 
de Menezes, L. M., \& Houllier, M. A. (2015). Germany's Nuclear Power Plant Closures and The Integration of Electricity Markets in Europe. Energy Policy, $85,357-368$.

EC. (2011). Energy Roadmap 2050. https://ec.europa.eu/energy/sites/ener/ files/documents/sec_2011_1565_part2.pdf. Accessed 9 Oct 2017.

EC. (2015). Intended Nationally Determined Contribution of the EU and its Member States. http://www4.unfccc.int/submissions/INDC/Published\%20 Documents/Latvia/1/LV-03-06-EU\%20INDC.pdf. Accessed 11 Jan 2017.

EC. (2016). Clean Energy for All Europeans - Unlocking Europe's Growth Potential. Press Release. http://europa.eu/rapid/press-release_IP-16-4009_en.htm. Accessed 11 Jan 2017.

Edwards, D. P., Fisher, B., \& Boyd, E. (2010). Protecting Degraded Rainforests: Enhancement of Forest Carbon Stocks Under REDD+. Conservation Letters, 3(5), 313-316.

EIA. (2016). Total Petroleum and Other Liquids Production 2015. http://www. eia.gov/beta/international/index.cfm?topL=imp. Accessed 10 Jan 2017.

European Council. (1990). Presidency Conclusions, Annex II: The Environmental Imperative. Dublin: Council of the European Union. SN 60/1/90, 25-26 June.

Eurostat. (2017a). Energy Statistics: Quantities. http://ec.europa.eu/eurostat/ web/energy/data/database. Accessed 15 Oct 2017.

Eurostat. (2017b). Electricity Price Statistics. http://ec.europa.eu/eurostat/statistics-explained/index.php/Electricity_price_statistics. Accessed 18 Oct 2017.

Flassbeck, H. (2016). The End of the Energiewende? Energy Post. http://energypost.eu/end-energiewende/. Accessed 17 Oct 2017.

Friedrichs, J., \& Inderwildi, O. R. (2013). The Carbon Curse: Are Fuel Rich Countries Doomed to High CO2 Intensities? Energy Policy, 62, 1356-1365.

Fuglestvedt, J. S., \& Kallbekken, S. (2015). Climate Responsibility: Fair Shares? Nature Climate Change. https://doi.org/10.1038/nclimate2791.

Geological Survey. (1958, February 24). FN-konferanse $i$ Geneve 24. februar 1958 om havets folkerett. Letter to the Ministry of Foreign Affairs of Norway. http:// www.geo365.no/oljehistorie/et-mye-omtalt-brev/. Accessed 10 Apr 2016.

German Advisory Council on the Environment. (2011). Pathways Towards a 100\% Renewable Electricity System. https://www.umweltrat.de/SharedDocs/ Downloads/EN/02_Special_Reports/2011_10_Special_Report_Pathways_ renewables.html?_blob=publicationFileS. Accessed 6 Oct 2017.

Gjelsvik, E. (2017). -Norsk energipolitikk henger ikke på greip. https://enerwe. no/kraft/norsk-energipolitikk-henger-ikke-pa-greip/. Accessed 30 Oct 2017.

Granlund, L.L. (2014). Uten Enova - ingen vindkraft i Europas beste 'vindland'. In N. K. Nakstad (Ed.), Etablering av vindkraft $i$ Norge (pp. 6-7). Enova Report 2014:5. 
Gullberg, A. T. (2013). The Political Feasibility of Norway and the 'Green Battery' of Europe. Energy Policy, 57, 615-623.

GWEC. (2017). Global Wind Statistics 2017. http://www.gwec.net/wp-content/ uploads/vip/GWEC_PRstats2016_EN_WEB.pdf. Accessed 7 Nov 2017.

Hagem, B. (2016, November 16). Gronn Handel. Presentation at the Seminar 'Norge som Europas grønne batteri: Visjoner og realiteter'. Research Council of Norway.

Handegård, O. (2016). Høringsuttalelse om endringer i energiloven $\$ 4-2-$ Flere eksportkabler til EU?. https://www.regjeringen.no/contentassets/e431528b 7564474e9af680cbb67a07e0/odd-handegard.pdf. Accessed 30 Oct 2017.

Handegård, O. (2017). Det brune skiftet - om å misforstå norsk energipolitikk. https://steigan.no/2017/10/22/det-brune-skiftet-om-a-misforsta-norskenergipolitikk/. Accessed 30 Oct 2017.

Haugan, B. (2016). Statoil-sjefen: Lofoten-utbygging er bra for klimaet. http:// www.vg.no/nyheter/innenriks/statoil/statoil-sjefen-lofoten-utbygging-erbra-for-klimaet/a/23778672/. Accessed 11 Jan 2017.

Haugan, B., \& Vågenes, H. (2016, September 12). Tidligere Statoil-topp tror strømprisene dobles. Verdens Gang. http://www.vg.no/nyheter/innenriks/ stroemprisene/tidligere-statoil-topp-tror-stroemprisene-dobles/a/ 23786136/. Accessed 11 Jan 2017.

Hermansen, E. A. (2015). Policy Window Entrepreneurship: The Backstage of the World's Largest REDD+ Initiative. Environmental Politics, 24(6), 932-950. https://doi.org/10.1080/09644016.2015.1063887.

Hesterberg, T., Bunn, W., \& Lapin, C. (2009). An Evaluation of Criteria for Selecting Vehicles Fueled with Diesel or Compressed Natural Gas. Sustainability: Science, Practice and Policy, 5(1), 20-30. https://doi.org/10.1080/1548773 3.2009.11908025.

Holst, S. M., Thomassen, M., Nekså, P., Tomasgard, A., Tangen, G., et al. (2016). Hydrogen: Verdikjeder og potensial. http://blog.sintefenergy.com/wp-content/uploads/2016/06/Underlagsnotat_hydrogen_SINTEF.pdf. Accessed 9 Nov 2017.

Hovden, E., \& Lindseth, G. (2004). Discourses in Norwegian Climate Policy: National Action or Thinking Globally? Political Studies, 52(1), 63-81.

Killingtveit, Å. (2016). Norges ressurser/muligheter, magasiner, effekt, pumpekrafte. ht t p : / / www.cedren.no/Portals / Cedren / $3-$ Norges\% 20 ressursermuligheter $\% 2 \mathrm{C} \% 20$ magasiner $\% 2 \mathrm{C} \% 20$ pumpekraft $\% 20$ etc-Seminar\%20gront $\% 20$ batteri-16112016-Anund\%20Killingtveit-NTNU.pdf. Accessed 30 Oct 2017.

Klassekampen. (2015). Flere eksportkabler til EU? www.klassekampen.no/article/20151123/PLUSS/151129908. Accessed 30 Oct 2017. 
Kojima, M., \& Koplow, D. (2015). Fossil Fuel Subsidies: Approaches and Valuation (World Bank Policy Research Working Paper 7220). https://openknowledge. worldbank.org/handle/10986/21659. Accessed 11 Nov 2017.

Koplow, D. (2009). Measuring Energy Subsidies Using the Price-Gap Approach: What Does It Leave Out? https://www.iisd.org/pdf/2009/bali_2_copenhagen_ff_subsidies_pricegap.pdf

Krogh, A. (2016). Statoil vil investere 60 milliarder $i$ Johan Castberg. https:// www.nrk.no/finnmark/statoil-vil-investere-60-milliarder-i-johan-castberg-1.13132316. Accessed 11 Jan 2017.

Lahn, B., \& Wilson Rowe, E. (2015). How to Be a 'Front-Runner': Norway and International Climate Politics. In B. de Carvalho \& I. B. Neumann (Eds.), Small States and Status Seeking. London: Routledge.

Lewis, H. Ø. (2017). Statoil har brukt 20 av 500 mrd. på fornybarprosjekter. https://sysla.no/gronn/statoil-har-brukt-20-av-500-milliarder-kroner-pafornybarprosjekter $/$ ? code $=13380214 \mathrm{ad} 8 \mathrm{a} 46 \mathrm{da} 8 \mathrm{c} 918 \mathrm{c} 0 \mathrm{fcf} 8 \mathrm{e} 1 \mathrm{ff} 8835 \mathrm{a} 2 \mathrm{~b} 95$. Accessed 30 Oct 2017.

Lie, Ø. (2013a). Energiminister Tord Lien vil ha dyrere strøm. Teknisk ukeblad. http://e24.no/energi/energiminister-tord-lien-vil-ha-dyrerestroem/22601855. Accessed 7 Nov 2017.

Lie, Ø. (2013b). Vil eksportere overskuddskraft som hydrogen. Teknisk ukeblad. https://www.tu.no/artikler/vil-eksportere-overskuddskraft-som-hydrogen/234040. Accessed 11 Nov 2017.

Lindström, A., \& Ruud, A. (2017). Whose Hydropower? From Conflictual Management into an Era of Reconciling Environmental Concerns: A Retake of Hydropower Governance Towards Win-Win Solutions? Sustainability, 9(8), 2-18.

Lysvold, S. (2016). Statoil stadig mer hissig på Lofoten. https://www.nrk.no/nordland/statoil-stadig-mer-hissig-pa-lofoten-1.13085122. Accessed 11 Jan 2017.

Madrid, R. L. (2008). The Rise of Ethnopopulism in Latin America. World Politics, $60(3), 475-508$.

Matthews, R. B., van Noordwijk, M., Lambin, E., Meyfroidt, P., Gupta, J., et al. (2014). Implementing REDD+ (Reducing Emissions from Deforestation and Degradation): Evidence on Governance, Evaluation and Impacts from the REDD-ALERT Project. Mitigation and Adaptation Strategies for Global Change, 19(6), 907-925. https://doi.org/10.1007/s11027-014-9578-z.

Mersky, A. C., Sprei, F., Samaras, C., \& Qian, Z. (2016). Effectiveness of Incentives on Electric Vehicle Adoption in Norway. Transportation Research Part D: Transport and Environment, 46, 56-68. https://doi.org/10.1016/j. trd.2016.03.011.

Mirza, M. F., \& Bergland, O. (2015). Market Power in Norwegian Electricity Market: Are the Transmission Bottlenecks Truly Exogenous? The Energy Journal, 36(4). 
Moser, A., Maaz, A., Baumann, C., \& Schäfer, A. (2015). Value of Large-scale Balancing and Storing from Norwegian Hydropower for the German Power system and Generation Portfolios. Institut for Elektrische Anlagen und Energiewirtschaft/ E.ON Kraftwerke. http://www.cedren.no/Portals/ Cedren/Report_EON_Norway_final_stc20151103.pdf? ver=2015-12-02-150833-010. Accessed 11 Nov 2017.

Mudde, C. (2004). The Populist Zeitgeist. Government and Opposition, 39(4), 542-563.

Mundaca, G. (2017). How Much Can CO 2 Emissions be Reduced if Fossil Fuel Subsidies Are Removed? Energy Economics, 64, 91-104. https://doi. org/10.1016/j.eneco.2017.03.014.

Naustdalslid, J. (1975). Oljesaka i statlege komitear og utval. In K. B. Wyller \& T. C. Wyller (Eds.), Norsk oljepolitikk (pp. 11-37). Oslo, Norway: Gyldendal.

Njarga, B. (2016). Så mye betaler du faktisk i avgifter for drivstoff. http://www. dinside.no/okonomi/sa-mye-betaler-du-faktisk-i-avgifter-for-drivstoff/61904306. Accessed 11 Jan 2017.

Nordea.(2016). Statoil Fuel \& Retail: Advancing International Cash Management. http://www.nordea.com/Images/20-105931/statoil-fuel-retail-case-studytreasury.pdf. Accessed 11 Jan 2017.

O'Sullivan, M., Overland, I., Sandalow, D., Behrens, A., Bhatiya, N., et al. (2017). The Geopolitics of Renewable Energy. Columbia University and Harvard University. https://www.researchgate.net/publication/317954274_The_ Geopolitics_of_Renewable_Energy. Accessed 15 Oct 2017.

Oberthür, S., \& Pallemaerts, M. (2010). The EU's Internal and External Climate Policies: An Historical Overview. In S. Oberthür \& M. Pallemaerts (Eds.), The New Climate Policies in the European Union (pp. 31-63). Brussels: Brussels University Press.

Orttung, R., \& Overland, I. (2011). Russia and the Formation of a Gas Cartel. Problems of Post-Communism, 58(3), 53-66. https://www.researchgate.net/ publication/274678269_Russia_and_the_Formation_of_a_Gas_Cartel. Accessed 8 Nov 2017.

Overland, I. (2010). Subsidies for Fossil Fuels and Climate Change: A Comparative Perspective. International Journal of Environmental Studies, 67(3), 303-317. https://www.researchgate.net/publication/240515305_Subsidies_for_fossil_ fuels_and_climate_change_A_comparative_perspective. Accessed 11 Nov 2017.

Overland, I. (2015). Future Petroleum Geopolitics: Consequences of Climate Policy and Unconventional Oil and Gas. Handbook of Clean Energy Systems, 1-29. https://www.researchgate.net/publication/281774890_Future_ Petroleum_Geopolitics_Consequences_of_Climate_Policy_and_ Unconventional_Oil_and_Gas. Accessed 11 Nov 2017. 
Overland, I. (2017). The Hunter Becomes the Hunted: Gazprom Encounters EU Regulation. In S. Andersen, A. Goldthau \& N. Sitter (Eds), Energy Union: Europe's New Liberal Mercantilism? (pp. 115-130). Basingstoke, UK: Palgrave Macmillan. https://www.researchgate.net/publication/309502480_The_ Hunter_Becomes_the_Hunted_Gazprom_Encounters_EU_Regulation. Accessed 11 Nov 2017.

Overland, I. (2018a). Did China bankroll Russia's annexation of Crimea? The role of Sino-Russian energy relations. In H. Blakkisrud \& E. Wilson Rowe (Eds), Russia's Turn to the East: Domestic Policymaking and Regional Cooperation (pp. 95-118). Cham, Switzerland: Palgrave Pivot. https://www.researchgate. net/publication/322158372. Accessed 17 Jan 2018.

Overland, I. (2018b). Norway: Public Debate and the Management of Petroleum Resources and Revenues. In I. Overland (Ed.), Public Brainpower: Civil Society and Natural Resource Management (pp. 217-245). London: Palgrave. https://www.researchgate.net/publication/320657120_Norway_Public_ Debate_and_the_Management_of_Petroleum_Resources_and_Revenues. Accessed 11 Nov 2017.

Overland, I., \& Kjaernet, H. (2009). Russian Renewable Energy: The Potential for International Cooperation. Aldershot, UK: Ashgate.

Overland, I., \& Krivorotov, A. (2015). Norwegian-Russian Political Relations and Barents Oil and Gas Developments. In A. Bourmistrov, F. Mellemvik, A. Bambulyak, O. Gudmestad, I. Overland \& A. Zolotukhin (Eds.), International Arctic Petroleum Cooperation: Barents Sea Scenarios (pp. 97-96). Abingdon, UK: Routledge. https://www.researchgate.net/publication/320357572_2015_-_ Norwegian_Russian_political_relations_and_Barents_Sea_oil_and_gas. Accessed 11 Nov 2017.

Overland, I., \& Kutschera, H. (2011). Pricing Pain: Social Discontent and Political Willpower in Russia's Gas Sector. Europe-Asia Studies, 63(2), 311-331 https:// www.researchgate.net/publication/254248306_Pricing_Pain_Social_ Discontent_and_Political_Willpower_in_Russia\%27s_Gas_Sector.

Overland, I., Suryadi, B., \& Win, U. T. (2016). Energy Subsidy Reform: An International Comparative Perspective on Myanmar. https://www.researchgate.net/publication/313652077_Energy_Subsidy_Reform_An_ International_Comparative_Perspective_on_Myanmar. Accessed 11 Nov 2017.

Pinchasik, D. R., \& Hovi, I. B. (2017). A CO 2 -fund for the Transport Industry: The Case of Norway. Transport Policy, 53, 186-195. https://doi.org/10.1016/j. tranpol.2016.08.007.

Riisnæs, I. G. (2017, October 27). Sol og vind danker ut vannkraft. Dagens Neringsliv, p. 12.

Rive, N., Torvanger, A., \& Fuglestvedt, J. S. (2006). Climate Agreements Based on Responsibility for Global Warming: Periodic Updating, Policy Choices, and 
Regional Costs. Global Environmental Change, 16(2), 182-194. https://doi. org/10.1016/j.gloenvcha.2006.01.002.

Rogalands Avis. (2013). Trenger vi flere eksportkabler for strøm? http://www.dagsavisen.no/rogalandsavis/trenger-vi-flere-eksportkabler-for-strom-1.646435. Accessed 30 Oct 2017.

Roland, K., \& Lien, T. (2017, January, 6). Kraftmarkedet er i et uføre. Dagens Neringsliv, p. 28.

Romanova, T. (2016). Is Russian Energy Policy Towards the EU Only About Geopolitics? The Case of the Third Liberalisation Package. Geopolitics, 21(4), 857-879. https://doi.org/10.1080/14650045.2016.1155049.

Rummelhoff, I. (2016, August 30). Derfor satser Statoil grønt, Stavanger Aftenblad. http://www.aftenbladet.no/meninger/debatt/Derfor-satser-Statoil-gront487373b.html. Accessed 11 Jan 2017.

Rygg, B. J. (2015). Renewable Energy as a Community Concern How Local Communities Face the Challenge of Increasing Use and Production of Renewable Energy (NTNU $\mathrm{PhD}$ Thesis). https://brage.bibsys.no/xmlui/handle/11250/284414. Accessed 11 Nov 2017.

Ryghaug, M., \& Toftaker, M. (2016). Creating Transitions to Electric Road Transport in Norway: The Role of User Imaginaries. Energy Research o Social Science, 17, 119-126. https://doi.org/10.1016/j.erss.2016.04.017.

Sxtre, E. (2017a). Statoil: Skal målene fra Paris-avtalen nås, må også mye olje og gass forbli $i$ bakken. https://www.aftenposten.no/meninger/kronikk/i/ qG9Q1/Statoil-Skal-malene-fra-Paris-avtalen-nas_-ma-ogsa-mye-olje-og-gassforbli-i-bakken--Eldar-Satre. Accessed 30 Oct 2017.

Sxtre, I. (2017b). MDGs naivitet og ideologi. https://www.aftenbladet.no/meninger/debatt/i/Wroek/MDGs-naivitet-og-ideologi. Accessed 30 Oct 2017.

Sxverud, I. A., \& Wettestad, J. (2005). Norway and Emissions Trading: From Global Front-runner to EU Follower. International Environmental Agreements, 6(1), 91-108.

Sanderud, P. (2017, January 12). Norge skal ikke være gratisbatteri. Dagens Neringsliv.

Sharples, J. D. (2016). The Shifting Geopolitics of Russia's Natural Gas Exports and Their Impact on EU-Russia Gas Relations. Geopolitics, 21(4), 880-912.

Solvang, E., Charmasson, J., Sauterlaute, J., Harby, A., Killingtveit, Å., et al. (2014). Norwegian Hydropower for Large Scale Electricity Balancing Needs. Pilot Study of Technical, Environmental and Social Challenges (Sintef Report A7227). https://brage.bibsys.no/xmlui/handle/11250/297142. Accessed 11 Nov 2017.

Statoil. (2017). Climate. https://www.statoil.com/no/hvordan-og-hvorfor/klimaendringer.html. Accessed 6 Nov 2017.

Staurset, K. B. (2011). Lengre kyst og flere oyer. www.statkart.no/ Lengre+kyst+og+flere+øyer.d25-SwZrY27.ips. Accessed 10 Jan 2017. 
Sweijs, T., de Ridder, M., de Jong, S., Oosterveld, W., Frinking, E., et al. (2014). Time to Wake Up: The Geopolitics of EU 2030 Climate and Energy Policies. The Hague Centre for Strategic Studies (HCSS).

Trademap. (2017). Trademap. http://www.trademap.org/Country_ SelProductCountry_TS.aspx. Accessed 10 Dec 2017.

Ulvestad, M., \& Overland, I. (2012). Natural Gas and CO2 Price Variation: Impact on the Relative Cost-Efficiency of LNG and Pipelines. International Journal of Environmental Studies, 69(3), 407-426 https://www.researchgate. net/publication/261221877. Accessed 18 January 2018.

Unruh, G. C. (2000). Understanding Carbon Lock-in. Energy Policy, 28(12), 817-830. https://doi.org/10.1016/s0301-4215(00)00070-7.

Vattenfall. (2017). Wind Power at Vattenfall. https://corporate.vattenfall.com/ about-energy/renewable-energy-sources/wind-power/wind-power-at-vattenfall/. Accessed 18 Oct 2017.

Weir, D. (2017). Vindkraft: produksjon i 2016 (NVE Report 12-2017). http://publikasjoner.nve.no/rapport/2017/rapport2017_12.pdf. Accessed 6 Nov 2017.

Zhang, X., Myhrvold, N. P., Hausfather, Z., \& Caldeira, K. (2016a). Climate Benefits of Natural Gas as a Bridge Fuel and Potential Delay of Near-Zero Energy Systems. Applied Energy, 167(1), 317-322.

Zhang, Y., Qian, Z., Sprei, F., \& Li, B. (2016b). The Impact of Car Specifications, Prices and Incentives for Battery Electric Vehicles in Norway: Choices of Heterogeneous Consumers. Transportation Research Part C: Emerging Technologies, 69, 386-401. https://doi.org/10.1016/j.trc.2016.06.014.

Open Access This chapter is licensed under the terms of the Creative Commons Attribution 4.0 International License (http://creativecommons.org/licenses/ by $/ 4.0 /$ ), which permits use, sharing, adaptation, distribution and reproduction in any medium or format, as long as you give appropriate credit to the original author(s) and the source, provide a link to the Creative Commons license and indicate if changes were made.

The images or other third party material in this chapter are included in the chapter's Creative Commons license, unless indicated otherwise in a credit line to the material. If material is not included in the chapter's Creative Commons license and your intended use is not permitted by statutory regulation or exceeds the permitted use, you will need to obtain permission directly from the copyright holder.

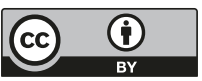

